\title{
Intracranial Intermediate-Grade Melanocytic Neoplasm: Case Report Associated with Nevus of Ota
}

\author{
Dorothy Sze Wing Hung, Calvin Hoi Kwan Mak*, Fung Ching Cheung \\ Department of Neurosurgery, Queen Elizabeth Hospital, Hong Kong, China \\ Email:*mhk349@ha.org.hk
}

How to cite this paper: Hung, D.S.W., Mak, C.H.K. and Cheung, F.C. (2017) Intracranial Intermediate-Grade Melanocytic Neoplasm: Case Report Associated with Nevus of Ota. Open Journal of Modern Neurosurgery, 7, 65-74.

https://doi.org/10.4236/ojmn.2017.73008

Received: June 2, 2017

Accepted: July 2, 2017

Published: July 5, 2017

Copyright ( 92017 by authors and Scientific Research Publishing Inc. This work is licensed under the Creative Commons Attribution International License (CC BY 4.0).

http://creativecommons.org/licenses/by/4.0/

\begin{abstract}
Melanocytic lesions of the CNS are rare tumours originating from melanocytes that are present in the leptomeninges. They consist of a spectrum of pigmented tumours ranging from melanocytoma to melanoma. A small group of these tumours have histopathological features between those of a benign melanocytoma and a malignant melanoma; these present as intermediate grade melanocytic neoplasms. Naevus of Ota is a blue hyperpigmented dermal lesion characterized by increased number of melanocytes in the distribution of ophthalmic and maxillary divisions of the trigeminal nerve. The association of an intracranial intermediate-grade melanocytic neoplasm with a nevus of Ota is extremely rare, with only 2 cases reported in the literature to date. As a result, their behavior and progression are still poorly understood. We present the first case of a familial naevus of Ota associated with intermediate-grade melanocytic neoplasm.
\end{abstract}

\section{Keywords}

Melanocytic Neoplasm, Leptomeninges, Nevus of Ota

\section{Case Report}

A 50-year-old female with good past health presented to Queen Elizabeth Hospital on $7^{\text {th }}$ April, 2016, with fall and left side weakness.

Upon presentation, her vitals were stable. She was fully conscious and orientated, with right side pupil measuring $4 \mathrm{~mm}$ and left side $3 \mathrm{~mm}$. There was no deficit of other cranial nerves. She suffered from dense left hemiplegia without sensory deficit. Plain computer tomography (CT) of brain demonstrated a $4 \mathrm{~cm}$ right temporal hyperdense lesion with local mass effect (Figure 1).

Emergency craniotomy and gross total excision of the lesion were performed. 


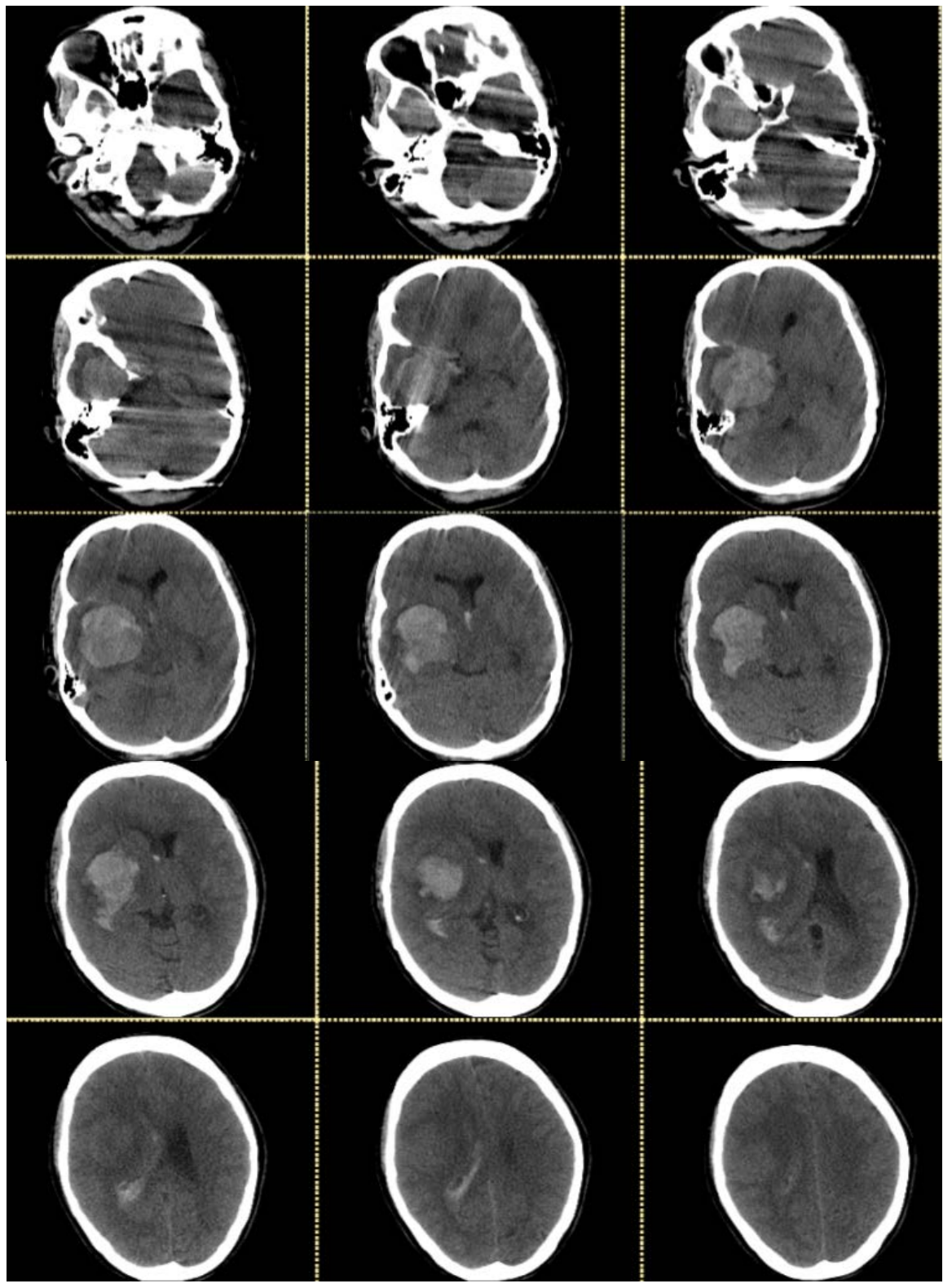

Figure 1. CT brain upon admission showing right temporal haemorrhage.

Intraoperative findings were suggestive of a pigmented lesion with haemorrhage, displacing the right internal carotid artery, right middle cerebral artery, and right third nerve.

Histopathological examination later revealed features of a melanocytic proliferation with worrisome histologic features including elevated mitosis and focal atypia, but no necrosis or anaplasia. Final pathological diagnosis was intermediate grade melanocytic neoplasm. On immunohistochemistry the tumour cells showed diffuse and strong positivity for HMB45 and patchy expression of S-100 protein. BRAF gene mutation was negative.

A detailed head-to-toe physical examination showed a left eyebrow pigmented naevus in the distribution of cranial nerve V1, which has been present without change for many years. There were no other suspicious melanocytic lesions. The 
patient had no family history of melanoma.

In view of the intracranial findings, an incisional biopsy of the eyebrow lesion was performed. The final pathology was dermal dendritic melanocytosis, which can be compatible with the diagnosis of naevus of Ota.

The patient further underwent whole body PET-CT and CT angiography of the brain. Both showed unremarkable findings.

Upon further questioning, the patient revealed that her 21-year-old son also has a similar left eyebrow pigmented lesion, which has been present for 3 years with no change in appearance. He had unremarkable past medical history. We performed an MRI of the brain for him, which was unremarkable.

Following the operation, the patient had transient right third nerve palsy (Figure 2), which spontaneously resolved at 3 months. Follow up MRI brain showed no recurrence at 4 months and 8 months after operation (Figure 3 ). Upon follow up at the outpatient clinic 8 months post operatively, she had no neurological deficit, and has returned to work full-time as a hospital janitor.

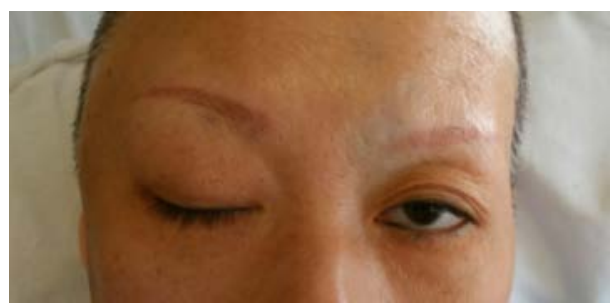

Figure 2. Patient with left naevus of Ota involving the distribution of the first (V1) branch of the trigeminal nerve. Post-operative $3^{\text {rd }}$ nerve palsy is seen.

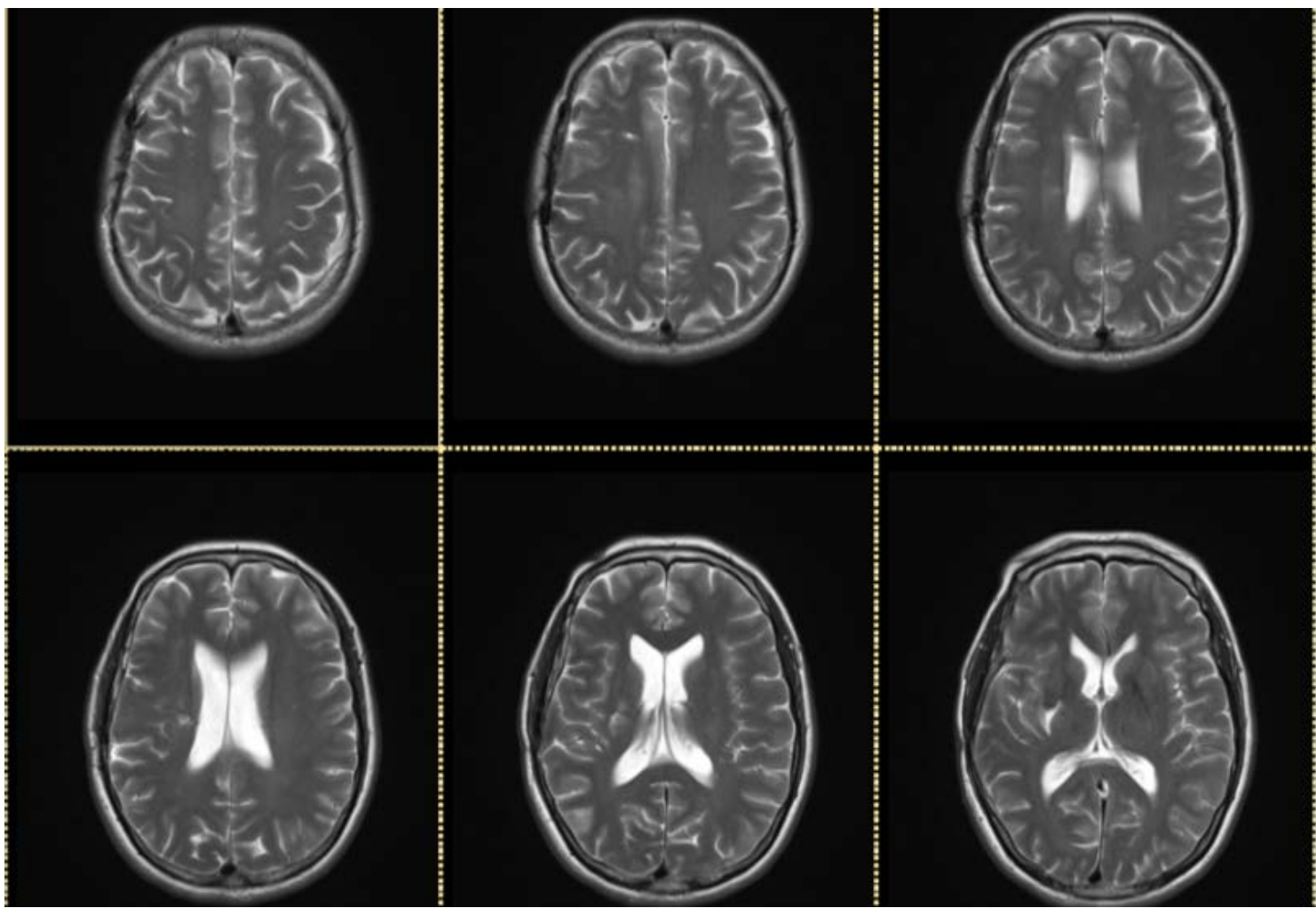




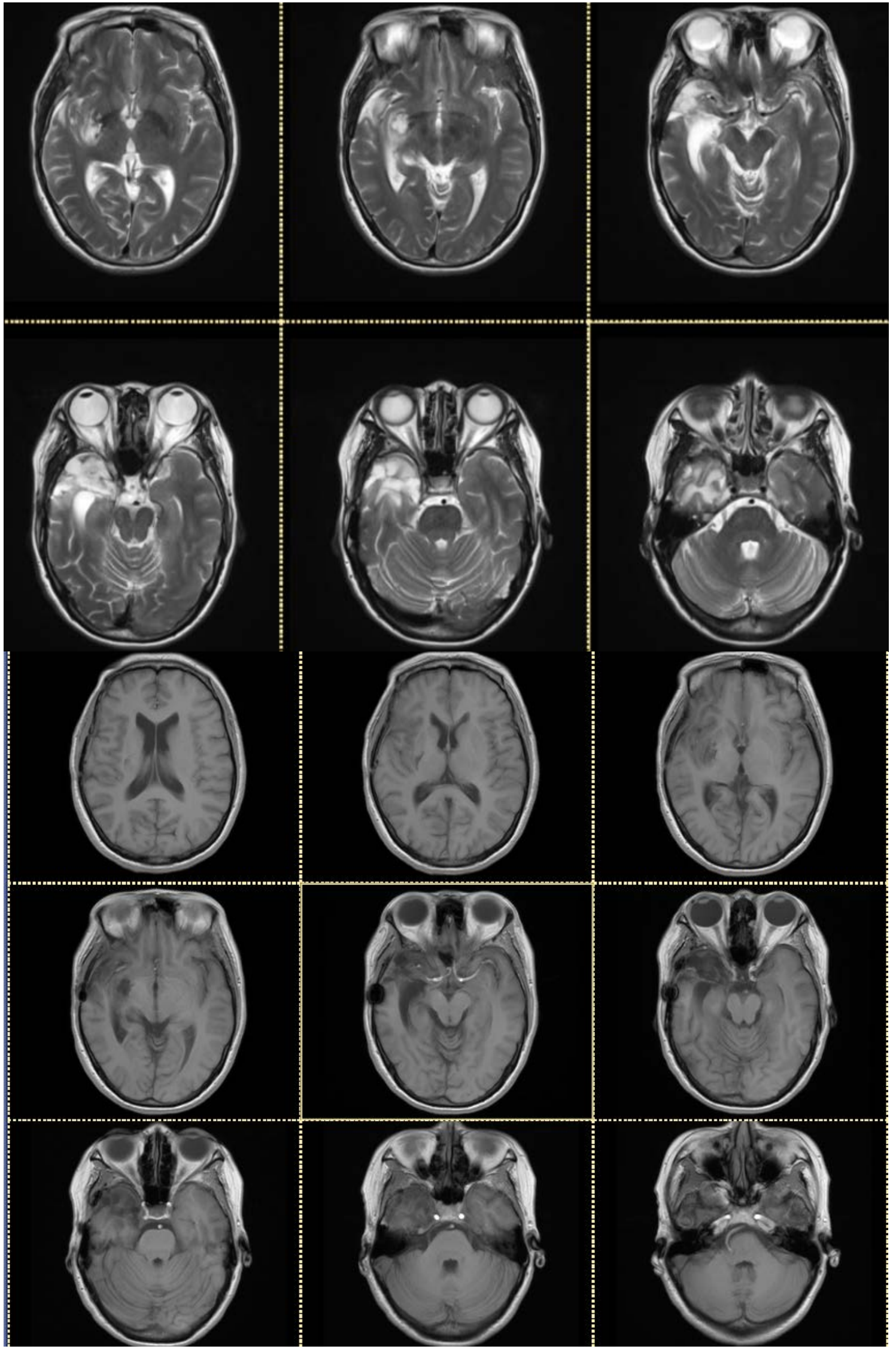

Figure 3. Follow up MRI 8 months post-operatively. 


\section{Discussion}

Melanocytes are of neural crest in origin. Melanocytic neoplasm of the CNS associated with naevus of Ota is a rare disease. The naevus of Ota is a blue pigmented lesion that involves unilateral skin or mucous membranes in areas supplied by the trigeminal nerve [1]. It is thought to develop when migration of melanoblasts is arrested at the dermis instead of the dermoepidermal junction. It has been speculated that intracranial melanocytoma associated with the naevus of Ota both originate from melanocytes derived from the neural crest.

Primary CNS melanocytic tumours represent a spectrum of disease from well-differentiated melanocytoma to malignant melanoma. These are rare tumours with an estimated incidence 0.9 per 10 million for melanocytomas and 0.5 cases per 10 million for primary malignant melanomas [2]. They are most commonly intracranial, but can involve the spinal column, where they are most often intradural and extramedullary [3]. A small group of these tumours have histopathological features between those of a benign melanocytoma and a malignant melanoma; these are labeled as intermediate grade melanocytic neoplasm [4].

\section{Literature Review}

Review of the literature revealed that melanocytoma and intermediate grade melanocytic lesions can recur as malignant melanoma despite complete excision [5] [6]. This supports the previously proposed theory of melanocytoma, intermediate grade melanocytic neoplasm, and malignant melanoma as a continuous spectrum of disease, rather than each being a separate disease entity. With this knowledge, it is important to review these three diagnoses in conjunction with a naevus of Ota.

Literature search via Pubmed and EMBASE revealed 11 previous cases of melanocytoma and 2 cases of intermediate grade melanocytic neoplasm to date, and at least 11 cases of melanoma have been reported in conjunction with naevus of Ota (Table 1).

All reported cases of melanocytoma were ipsilateral to the naevus of Ota, where occasionally intermediate grade melanocytic neoplasms and melanoma have been found to occur contralateral to the cutaneous lesion. The reason for this is still largely unknown. We hypothesize that intracranial lesions that develop contralateral to the naevus of Ota may represent a more aggressive lesion and a different disease entity with higher risks of malignant transformation.

\section{Management and outcome}

Literature search showed that treatment options for patients with melanocytoma, intermediate grade melanocytic neoplasms, and melanomas were heterogeneous, with no established consensus. In most cases, patients underwent surgical excision, with a few cases also receiving radiotherapy or chemotherapy.

There have been few publications on the treatment of these neoplasms. Rades and colleagues published one of the more substantiated studies in 2004. The retrospective review of 89 meningeal melanocytomas showed that the five-yearsurvival rate was $100 \%$ in patients who received complete resection, but only 
Table 1. (a) Melanocytoma occurring in conjunction with a naevus of Ota, (b) Intermediate grade melanocytic neoplasm occurring in conjunction with a naevus of Ota, (c) Malignant melanoma occurring in conjunction with a naevus of Ota.

(a)

\begin{tabular}{|c|c|c|c|c|c|c|c|}
\hline Author/Year & Age/sex & Naevus of Ota & Site of intracranial lesion & Presenting symptoms & Excision & $\mathrm{RT} /$ chemo & Outcome \\
\hline Botticelli 1983 [7] & $43 / \mathrm{F}$ & Left & Leftmeckel's cave. & $\begin{array}{l}\text { Left CN4 palsy, left } \\
\text { ptosis, enophthalmos }\end{array}$ & Total & Yes/No & $\begin{array}{c}\text { Recur } 2 \text { years later, } \\
\text { subtotal excision + RT. } \\
\text { No more recurrence }\end{array}$ \\
\hline Moon WS 1992 [8] & $53 / \mathrm{M}$ & Right & $\begin{array}{l}\text { Right parietooccipital, } \\
\text { left frontal }\end{array}$ & $\begin{array}{l}\text { Right hemiparesis, } \\
\text { vomiting }\end{array}$ & Total & $\mathrm{No} / \mathrm{No}$ & Recurred \\
\hline $\begin{array}{c}\text { Piercecchi-Marti } 2002 \\
\text { [9] }\end{array}$ & $25 / \mathrm{M}$ & Right & Right frontoparietal & $\begin{array}{l}\text { Strabismus, headache, } \\
\text { grandma seizure }\end{array}$ & Total & $\mathrm{No} / \mathrm{No}$ & No recurrence \\
\hline Rahimi 2003 [10] & $17 / \mathrm{M}$ & Left & Left parietal & Headache, blindness & Total & $\mathrm{No} / \mathrm{No}$ & N/A \\
\hline Rutten 2005 [11] & $37 / \mathrm{F}$ & Right & Right olfactory groove & $\begin{array}{l}\text { Headache, loss visual } \\
\text { acuity }\end{array}$ & Total & $\mathrm{No} / \mathrm{No}$ & $\begin{array}{c}\text { Multifocal recurrence, } \\
\text { total excision } \rightarrow \text { RT. } \\
\text { No more recurrence }\end{array}$ \\
\hline Hino K 2005 [12] & $75 / \mathrm{F}$ & Right & $\begin{array}{l}\text { Right anterior clinoid } \\
\text { process, intraorbital }\end{array}$ & $\begin{array}{l}\text { Decreased vision, } \\
\text { disturbed consciousness }\end{array}$ & Partial & $\mathrm{No} / \mathrm{No}$ & $\begin{array}{c}\text { No recurrence } \\
\text { (but apallic state) }\end{array}$ \\
\hline Hao Pan 2011 [13] & $36 / \mathrm{M}$ & Right & Right cavernous sinus & Headache, ptosis & Subtotal & Yes/No & No recurrence \\
\hline Wu C $2011[14]$ & $36 / \mathrm{M}$ & Right & Right cavernous sinus & N/A & Total & No/No & N/A \\
\hline $\begin{array}{c}\text { Munoz-hidalgo } 2014 \\
{[15]}\end{array}$ & $15 / \mathrm{M}$ & Right & Right temporal & Headache, vomiting & Total & $\mathrm{No} / \mathrm{No}$ & No recurrence \\
\hline $\begin{array}{c}\text { Hongxu Chen } 2015 \\
{[16]}\end{array}$ & $20 / \mathrm{F}$ & Left & $\begin{array}{l}\text { Left cerebellar } \\
\text { hemisphere }\end{array}$ & Headache & Total & No/No & N/A \\
\hline $\begin{array}{c}\text { Mohammad Samadian } \\
2015[17]\end{array}$ & $19 / \mathrm{M}$ & Left & Left temporal & Seizure & Total & $\mathrm{No} / \mathrm{No}$ & No recurrence \\
\hline
\end{tabular}

(b)

\begin{tabular}{cccccccc}
\hline Author/Year & \multicolumn{2}{c}{ Age/sex } & Naevus of Ota Site of intracranial lesion & Presenting symptoms & Excision RT/chemo & Outcome \\
\hline $\begin{array}{c}\text { Marta Navas 2009 } \\
\text { [18] }\end{array}$ & 25/M & Right & Right temporal & Right CN3 palsy & Total & No/No & $\begin{array}{c}\text { Died post-op due to malignant } \\
\text { infarct of right hemisphere }\end{array}$ \\
Shin 2015 [19] & 56/F & Right & Left temporal & Headache, confusion & Total & Yes/No & No recurrence \\
\hline
\end{tabular}

(c)

\begin{tabular}{|c|c|c|c|c|c|c|c|}
\hline Author/Year & Age/sex & $\begin{array}{l}\text { Naevus } \\
\text { of Ota }\end{array}$ & $\begin{array}{l}\text { Site of intracranial } \\
\text { lesion }\end{array}$ & Presenting symptoms & Excision & RT/chemo & Outcome \\
\hline Enriquez 1973 [20] & $43 / \mathrm{M}$ & N/A & Pineal, meningeal & N/A & No & $\mathrm{No} / \mathrm{No}$ & Death \\
\hline Sang DN 1977 [21] & $58 / \mathrm{M}$ & Left & Right frontal & $\begin{array}{c}\text { Headache, incontinence, left CN7 } \\
\text { palsy }\end{array}$ & No & Yes/No & $\begin{array}{l}\text { Mass similar with no } \\
\text { progression } 6 \text { months later }\end{array}$ \\
\hline Horsey $1980[22]$ & $37 / \mathrm{F}$ & Left & $\begin{array}{l}\text { Left parietal, } \\
\text { left temporal bone }\end{array}$ & $\begin{array}{c}\text { Headache, CN6 palsy, nausea, } \\
\text { vomiting }\end{array}$ & $\begin{array}{c}\text { Total } \\
\text { (parietal) }\end{array}$ & Yes/No & No recurrence \\
\hline Sagar HJ 1983 [23] & $23 / \mathrm{F}$ & Right & Right temporal & Partial seizure & Total & $\mathrm{No} / \mathrm{No}$ & No recurrence \\
\hline Kubato 1988 [24] & $77 / \mathrm{M}$ & Left & Left temporal & $\begin{array}{c}\text { Disturbed consciousness, left } \\
\text { hemiparesis }\end{array}$ & Subtotal & No/Yes & Death 3 weeks post op \\
\hline $\begin{array}{c}\text { Hartmann LC } 1989 \\
\text { [25] }\end{array}$ & $41 / \mathrm{F}$ & Right & Right middle fossa & Headache & Total & No/No & $\begin{array}{c}\text { Recur } 6 \text { months later. } \\
\text { Observe. FU } 1 \text { year post op } \\
\text { unchanged }\end{array}$ \\
\hline Johnson RR 1999 [26] & $42 / \mathrm{M}$ & Left & Left occipital & $\begin{array}{l}\text { Headache, right upper } \\
\text { quadrantonopia, scotoma }\end{array}$ & Subtotal & Yes/No & $\begin{array}{l}\text { Static residual mass } 3 \\
\text { months post-op }\end{array}$ \\
\hline Azar 2010 [27] & $21 / \mathrm{M}$ & Left & $\begin{array}{l}\text { Right parietal, right } \\
\text { retrobulbar, right } \\
\text { cavernous sinus }\end{array}$ & Left hemiparesis + headache & $\begin{array}{c}\text { Total } \\
\text { (parietal) }\end{array}$ & Yes/Yes & Melanoma dissemination \\
\hline
\end{tabular}




\begin{tabular}{cccccccc}
\hline Wang J 2013 [28] & 52/F & Left & Left temporal & $\begin{array}{c}\text { Recurrence of previous melanoma } \\
\text { on MRI (16 months post-op) }\end{array}$ & Total & No/No & No recurrence \\
Wang J 2013 [28] & 33/F & Left & $\begin{array}{c}\text { Left tentorium } \\
\text { cerebelli }\end{array}$ & Headache, left facial numbness & Total & No/No & No recurrence \\
$\begin{array}{c}\text { Bharat Guthikonda } \\
2015[29]\end{array}$ & 32/F & Left & Right frontotemporal & Left side numbness & Total & No/No & N/A \\
\hline
\end{tabular}

$46 \%$ in those whose resection was incomplete. However, the survival rate improved to $100 \%$ in patients with incomplete resection and adjunct radiation therapy. Based on this, they concluded that complete tumor resection is the best therapeutic option, and in cases of incomplete resection, radiotherapy should be considered [30].

A retrospective review published by Rodriguez Y in 1992 on 81 cases of primary solitary intracranial melanoma also showed similar improved survival (19.6 \pm 2.3 months) in patients with complete removal of the tumour than patients undergoing partial removal or biopsy ( $9.3 \pm 2.4$ months). Patients who were not operated had a shorter survival than both surgical subgroups of patients [31].

Unfortunately, based on the above literature review, follow up data for patients with naevus of Ota and CNS melanocytic neoplasm is lacking and heterogeneous. However, from the limited evidence available, we can conclude that recurrence and even metastasis of the previously thought to be benign melanocytoma is not uncommon. Therefore, follow up with regular imaging is important.

\section{Conclusions}

Primary CNS intermediate grade melanocytic neoplasm and concomitant nevus of Ota have been rarely reported. This is the third reported case in literature so far. It is made more unique due to the fact that this is the first reported case in which a familial naevus of Ota occurs together with an intracranial melanocytic lesion.

There is no standard treatment protocol for intermediate grade melanocytic neoplasm occurring simultaneously with a Nevus of Ota. Based on data extrapolated from treatment for meningeal melanocytoma and primary intracranial melanoma, we propose that complete surgical excision should be considered as the best therapeutic option. Close monitoring with imaging of patients with intermediate grade melanocytic neoplasm post-operatively is important.

\section{References}

[1] Ota, M. (1939) Nevus Fusco-Caeruleus-Ophthalmo-Maxillaris. The Japanese Journal of Dermatology, 46, 369.

[2] Liubinas, S.V., Maartens, N. and Drummond, K.J. (2010) Primary Melanocytic Neoplasms of the Central Nervous System. Journal of Clinical Neuroscience, 17, 1227-1232. https://doi.org/10.1016/j.jocn.2010.01.017 
[3] Jaiswal, S., Vij, M., Tungria, A., Jaiswal, A.K., Srivastava, A.K. and Behari, S. (2011) Primary Melanocytic Tumors of the Central Nervous System: A Neuroradiological and Clinicopathological Study of Five Cases and Brief Review of Literature. Neurology India, 59, 413-419. https://doi.org/10.4103/0028-3886.82758

[4] Brat, D.J., Giannini, C., Scheithauer, B.W. and Burger, P.C. (1999) Primary Melanocytic Neoplasms of the Central Nervous Systems. The American Journal of Surgical Pathology, 23, 745-754. https://doi.org/10.1097/00000478-199907000-00001

[5] Abeygunaratne, R., Roberts, G., Gunawardena, L., Joseph, J. and Dawson, T. (2008) Final Diagnosis-Primary CNS Melanocytic Tumor of Intermediate Type Progressing to Metastatic Melanoma. University of Pittsburgh, Pittsburgh.

[6] Wang, F., Qiao, G., Lou, X., Song, X. and Chen, W. (2010) Malignant Transformation of Intracranial Meningeal Melanocytoma. Case Report and Review of the Literature. Neuropathology, 31, 414-420. https://doi.org/10.1111/j.1440-1789.2010.01160.x

[7] Boticelli, A.R., Villani, M., Angiari, P. and Peserico, L. (1983) Meningeal Melanocytoma of Meckel's Cave Associated with Ipsilateral Ota's Nevus. Cancer, 51, 23042310 .

https://doi.org/10.1002/1097-0142(19830615)51:12<2304::AID-CNCR2820511223> 3.0.CO;2-U

[8] Moon, W.S., Kim, J.H., Lee, D.G., Choi, Y.H. and Kim, S.S. (1992) Meningeal Melanocytoma Associated with Ota's Nevus. Report of a Case. The Korean Journal of Pathology, 26, 605-609.

[9] Piercecchi-Marti, M.-D., Mohamed, H., Liprandi, A., Gambarelli, D., Grisoli, F. and Pellissier, J.-F. (2002) Intracranial Meningeal Melanocytoma Associated with Ipsilateral Nevus of Ota. Journal of Neurosurgery, 96, 619-623. https://doi.org/10.3171/jns.2002.96.3.0619

[10] Rahimi-Movaghar, V. and Karimi, M. (2003) Meningeal Melanocytoma of the Brain and Oculodermal Melanocytosis (Nevus of Ota): Case Report and Literature Review. Neurosurgery, 59, 200-210. https://doi.org/10.1016/S0090-3019(02)01052-2

[11] Rutten, I., Bolle, S., Kaschten, B., Stevenaert, A., Deneufbourg, J.-M. and Deprez, M. (2005) Recurrent Intracranial Melanocytoma Associated with a Nevus of Ota. Acta Neurochirurgica, 147, 313-315.

[12] Hino, K., Nagane, M., Fujioka, Y. and Shiokawa, Y. (2005) Meningeal Melanocytoma Associated with Ipsilateral Nevus of Ota Presenting as Intracerebral Hemorrhage: Case Report. Neurosurgery, 56, 1376-1377. https://doi.org/10.1227/01.NEU.0000159716.45457.BC

[13] Pan, H., Wang, H. and Fan, Y. (2011) Intracranial Meningeal Melanocytoma Associated with Nevus of Ota. Journal of Clinical Neuroscience, 18, 1548-1550.

[14] Wu, C., Wang, H., Shi, Q.L., Ma, H.H. and Lu, Z.F. (2011) Meningeal Melanocytoma with Nevus Fuscoceruleusophthalmomaxillaris: Report of a Case. Chinese Journal of Pathology, 40, 194-195.

[15] Muñoz-Hidalgo, L., Lopez-Gines, C., Navarro, L., Callaghan, R.C., San Miguel, T., Gil-Benso, R., Quilis, V., Botella, L., Gonzalez-Darder, J. and Cerda-Nicolas, M. (2014) BRAF V600E Mutation in Two Distinct Meningeal Melanocytomas Associated with a Nevus of Ota. Journal of Clinical Oncology, 32, e72-e75. https://doi.org/10.1200/JCO.2013.48.8718

[16] Chen, H., Liu, W., Zhang, S., Xu, J. and Hui, X. (2015) Cerebellar Meningeal Melanocytoma Associated with Nevus of Ota: An Extremely Rare Case.

[17] Samadian, M., Nejad, A.M., Bakhtevari, M.H., Sabeti, S., Sharifi, G., Jabbari, R. and 
Rezaei, O. (2015) Primary Meningeal Melanocytoma in the Left Temporal Lobe Associated with Nevus Ota: A Case Report and Review of the Literature. Journal of Neurosurgery, 95, 225-231.

[18] Navas, M., Pascual, J.M., Fraga, J., Pedrosa, M., Shakur, S., Carrasco, R., Martínez, P., Manzanares, R. and de Sola, R.G. (2009) Intracranial Intermediate-Grade Meningeal Melanocytoma with Increased Cellular Proliferative Index: An Illustrative Case Associated with a Nevus of Ota. Journal of Neuro-Oncology, 95, 105-115. https://doi.org/10.1007/s11060-009-9907-3

[19] Shin, D., Sinha, M., Kondziolka, D.S., Kirkwood, J.M., Rao, U.N. and Tarhini, A.A. (2015) Intermediate-Grade Meningeal Melanocytoma Associated with Nevus of Ota: A Case Report and Review of the Literature. Melanoma Research, 25, 273-278. https://doi.org/10.1097/CMR.0000000000000163

[20] Enriques, R. and Egbert, B. (1973) Primary Malignant Melanoma of Central Nervous System. Archives of Pathology, 95, 392-395.

[21] Sang, D.N., Albert, D.M., Sober, A.J. and McMeekin, T.O. (1977) Nevus of Ota with Contralateral Cerebral Melanoma. Archives of Ophthalmology, 95, 1820-1824. https://doi.org/10.1001/archopht.1977.04450100122017

[22] Horsey, W.J., Bilbao, J.M., Nethercott, J., Myers, R. and Hoffman, H.J. (1980) University of Toronto Neurosurgical Rounds No. 2. Oculodermalmelanosis (Naevus of Ota) Complicated by Multiple Intracranial Tumors. The Canadian Journal of Neurological Sciences, 7, 101-107. https://doi.org/10.1017/S0317167100023477

[23] Sagar, H.J., Ilgren, E.B. and Adams, C.B. (1983) Nevus of Ota Associated with Meningeal Melanosis and Intracranial Melanoma. Case Report. Journal of Neurosurgery, 58, 280-283. https://doi.org/10.3171/jns.1983.58.2.0280

[24] Kabuto, M., Hayashi, M., Kawano, H., Kobayashi, H., Shirasaki, N., Hirose, S., Kubota, T. and Sugihara, H. (1988) Primary Intracranial Malignant Melanoma Associated with Nevus of Ota: A Case Report. No Shinkei Geka, 16, 875-880.

[25] Hartmann, L.C., Oliver, G.F., Winkelmann, R.K., Colby, T.V., Sundt, T.M. and O’Neill, B.P. (1989) Blue Nevus and Nevus of Ota Associated with Dural Melanoma. Cancer, 64, 182-186. https://doi.org/10.1002/1097-0142(19890701)64:1<182::AID-CNCR2820640131>3.0 .CO;2-P

[26] Johnson, R.R., Wong, J.H., Awad, I.A., Kim, J.H., Bolognia, J.L. and Sawaya, R. (1999) Hemorrhagic Lesion at the Tentorial Incisura in a Patient with Facial Nevus. Neurosurgery, 45, 1216-1221.

[27] Azar, M., Kazemi, F., Bahrami, E., Hejazian, E., Fereshtehnejad, S.-M., Ahmadi, A. and Yasari, M. (2010) Meningeal Melanomas Associated with Transforming Ota Nevus to Malignant Melanoma: A Case Report. Medical Journal of the Islamic Republic of Iran, 24, 163-168.

[28] Wang, J., Guo, Z.Z., Zhang, S.G., Wang, Y.J., Wang, Y.B. and Xing, D.G. (2013) Microsurgical Treatment of Meningeal Malignant Melanoma Accompanied by Nevus of Ota: Two Case Reports and a Literature Review. Melanoma Research, 23, 502-504. https://doi.org/10.1097/CMR.0000000000000026

[29] Guthikonda, B., Ahmed, O., Buckleair, L.J., Goodman, J.C., Powell, S.Z. and Yoshor, D. (2015) Primary CNS Malignant Melanoma Associated With a Contralateral Nevus of Ota in an African-American Female: Unique Case Report. Cancer and Clinical Oncology, 4.

[30] Rades, D., Schild, S.E., Tatagiba, M., Molina, H.A. and Alberti, W. (2004) Therapy of Meningeal Melanocytomas. Cancer, 100, 2442-2447.

https://doi.org/10.1002/cncr.20296 
[31] Rodriguezy Baena, R., Gaetani, P., Danova, M., Bosi, F. and Zappoli, F. (1992) Primary Solitary Intracranial Melanoma: Case Report and Review of the Literature. Surgical Neurology, 38, 26-37.

Submit or recommend next manuscript to SCIRP and we will provide best service for you:

Accepting pre-submission inquiries through Email, Facebook, LinkedIn, Twitter, etc. A wide selection of journals (inclusive of 9 subjects, more than 200 journals)

Providing 24-hour high-quality service

User-friendly online submission system

Fair and swift peer-review system

Efficient typesetting and proofreading procedure

Display of the result of downloads and visits, as well as the number of cited articles

Maximum dissemination of your research work

Submit your manuscript at: http://papersubmission.scirp.org/

Or contact ojmn@scirp.org 